\title{
YUNX TORQUILLA.
}

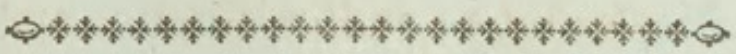

\section{CHARACTER GENERICUS.}

Roftrum teretiufculum, acuminatum.

Nares concavæ, denudatæ.

Lingua teres, lumbriciformis, longiffima, apice mucronata.

Pedes fcanforii.

$$
\text { Lin. Syft. Nat. p. } 17^{2} \text {. }
$$

CHARACTER SPECIFICUS, छc.

YUNX ex albo, grifeo, nigro, et ferrugineo varia

\section{JYNX s. TORQUILLA.}

$$
\text { Bell. av. } 76 . a .
$$

CUCULUS fubgrifeus maculatus, rectricibus nigris fafciis undulatis.

Lin Faun. Suec. 1. p. 78. t. 1. f. 78.

YUNX TORQUILLA.

$$
\text { Lin. Syft. Nat. p. } 172 .
$$

TORQUILLA STRIATA.

$$
\text { Briff. av. } 4 \cdot \mathrm{p} \cdot 7 \text {. }
$$

Varias Europæ partes incolit Torquilla, coloribus infignis elegantiffime difpofitis; e quibus conjunc- 
tis eximia exoritur pulchritudo, cum forfan figillatim confpectis vilefcat pretium. In Angliam Aprili menfe involat, cumque pullos aluerit, autumno vix finito, aliam fibi fedem quærit. Facillima auditu raro confpicitur: fallit enim oculos color cortici arboris nec longo intervallo fimillimus, aures feriente rapida et canora voce citifime iterata. Vivitur Torquilla eodem fere modo quo picis; linguaque eft huic, ut et illis longiffima, retractilis, quam ejaculando inter corticis rimas latitantia infecta prædatur. More quoque picorum ova deponit in arborum foraminibus, nidum pene nullum ftruens, fed molli ligno putrido infidens. Ovis dum incubat femina (quæ interdum quinque parit, interdum octo, alba admodum et femi-pellucida) collum corpufque, fi turbetur, miro modo contorquet quafi minitans: unde nomen Torquilla. Narrat doctiffimus Derhamus in præcellenti libro Phyfico-Theologico, fe puerum ab hac ave non femel perterritum fuiffe, nec e foramine, quo nidificarat ova aufum effe furripere, quafi a ferpente repulfum. Latet interdum nidus in cavo altiffimo; ut vix difcerni poffit: quod fi quis avem tangere conetur, illico more ferpentum fibilat; quod fibilum ipfi etiam pulli fortiter emittunt. Notandum eft tantam effe Torquillæ cum cuculo affinitatem, ut ab ipfo Linnæo femel in eodem genere conjuncta fit. 



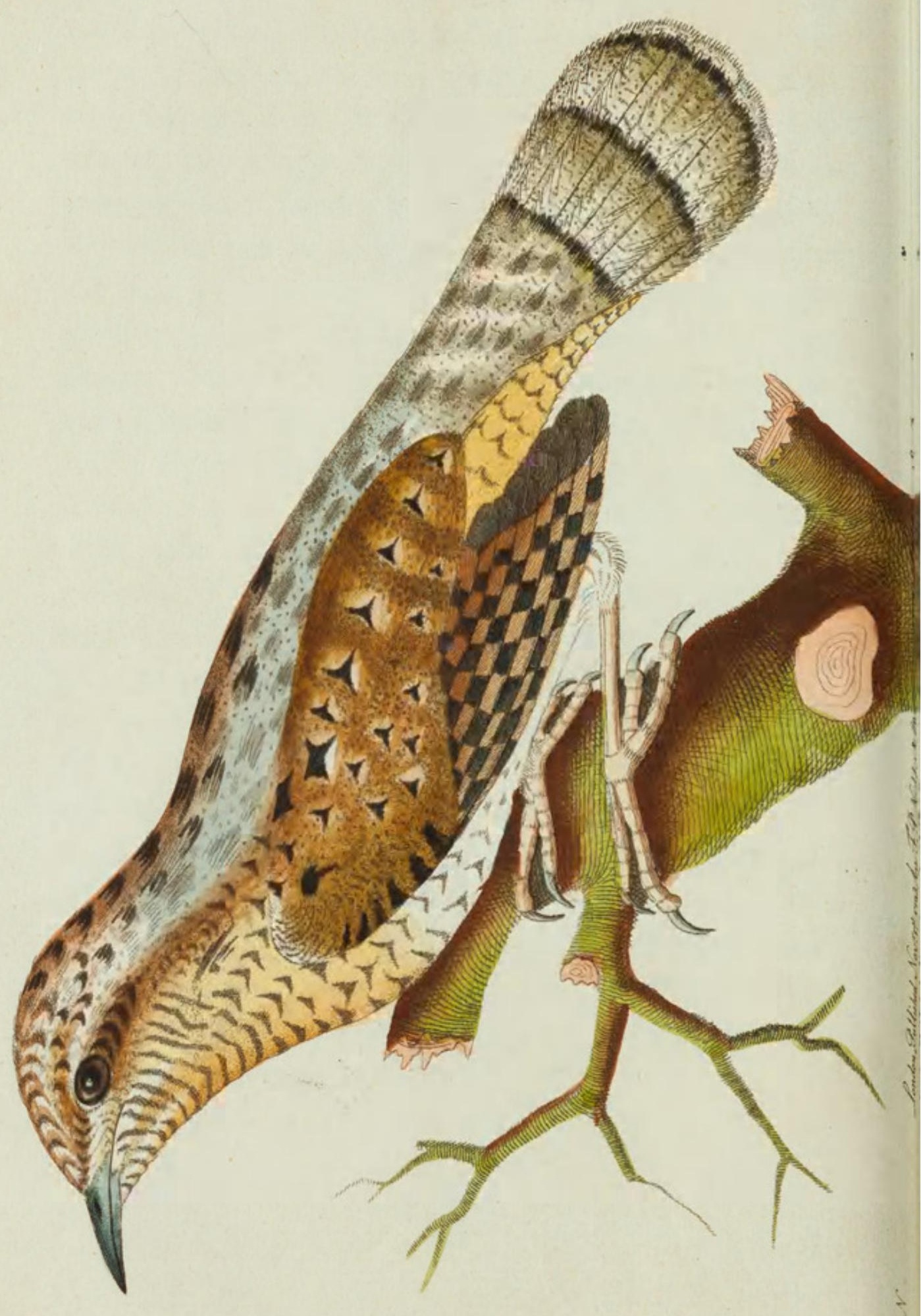




\section{THE}

\section{W R Y N E C K.}

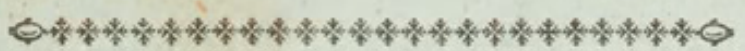

\section{GENERIC CHARACTER・}

Bill roundifh, flightly incurvated, weak. Tongue very long, cylindric, miffile, hard-pointed. Feet fcanforial, i.e. two toes forward and two backward.

\section{SPECIFIC CHARACTER, छ̋C.}

YUNX (WRYNECK) varied with black, white, grey, and ferruginous.

\section{THE WRYNECK.}

$$
\text { Will. orn. p. 138. t. } 22 .
$$

\section{LE TORCOL.}

$$
\begin{aligned}
& \text { Briff. orn. } 4 \cdot \mathrm{p} .4 \cdot \mathrm{pl} \text {. } 1 . \text { f. } 1 . \\
& \text { Buff. oif. } 7 \cdot \mathrm{p} \cdot 84 \cdot \mathrm{pl} \cdot 3 \cdot \\
& \text { Pl. enl. } 698 .
\end{aligned}
$$

The Wryneck, fo remarkable for the elegant difpofition of its colours, which tho' fingly confidered are far from brilliant, yet in combination produce fo beautiful an effect, is a native of feveral parts of Europe. In our own country it appears in the month of April, and after the breeding feafon

$$
\text { G } 2
$$


is over, again migrates before the appearance of winter, or during the autumnal feafon. Though by no means uncommon, it is much more frequently heared than feen; its note, which confifts of a quick fucceffion of feveral thrill tones, being one of the moft predominant amongit the vernal birds; while its colour bears fo near a refemblance to the bark of the trees it frequents, as to be inconfpicuous except on a very near approach.

In its mode of life the Wryneck bears a very ftrong affinity to the woodpecker tribe; and like thofe birds, is furnifhed with a very long, miffile tongue, which it darts into the crevices of trees, and thus catches the infects they contain. It lays its eggs in the holes of trees, in the manner of a woodpecker; making fcarce any neft, but contenting itfelf with the foft furface of the decayed wood. The eggs are from five to eight in number, very white, and femitranfparent. When the fermale is engaged in incubation, the has a habit, when difturbed, of wreathing herfelf into a number of extraordinary poftures in a threatening manner. It is from this circumftance that the name of Wryneck has been given to the bird. The celebrated Derham in his Phyfico-Theology obferves that, when a boy, he has more than once been deterred by thefe threatening contorfions from taking the eggs of the Wryneck, " daring no more to venture his hand " into the hole than if a ferpent had lodged in it." They fometimes, however, build in a hole fo deep as to be perfectly fecure from attacks of this kind; but if an attempt is made to reach them, they hifs 
in the manner of ferpents; and even the young exert this faculty in a moft ftriking degree. I fhould obferve that the Wryneck hears fome affinity to the Cuckow, with which it was once aflociated in the fame genus by Linnæus. 


\section{$2 \mathrm{BHL}$ Biodiversity Heritage Library}

Shaw, George. 1793. "The Wryneck, Yunx torquilla [PI. 156]." The Naturalist's Miscellany 5(LI), https://doi.org/10.5962/p.310735.

View This Item Online: https://www.biodiversitylibrary.org/item/276340

DOI: https://doi.org/10.5962/p.310735

Permalink: https://www.biodiversitylibrary.org/partpdf/310735

\section{Holding Institution}

Museums Victoria

\section{Sponsored by}

Atlas of Living Australia

\section{Copyright \& Reuse}

Copyright Status: Public domain. The BHL considers that this work is no longer under copyright protection.

This document was created from content at the Biodiversity Heritage Library, the world's largest open access digital library for biodiversity literature and archives. Visit BHL at https://www.biodiversitylibrary.org. 